\title{
Yttrium 90 Monoclonal Antibody T101
}

National Cancer Institute

\section{Source}

National Cancer Institute. Yttrium 90 Monoclonal Antibody T101. NCI Thesaurus. Code C29695.

A murine monoclonal antibody directed ag ainst the CD5 antigen and labeled with Yttrium90, a beta-emitting radioisotope. CD5 is a type-I transmembrane glycoprotein found on thymocytes, T-cells and a subset of B-cells. Yttrium 90 monoclonal antibody T101 may bind to and selectively irradiate and kill CD5-positive tumor cells. Yttrium 90 has a half-life of 2.5 days and can be administered on an outpatient basis. ( $\mathrm{NClO4}$ ) 